\title{
Investigating the Application and Distribution of Metadiscourse Features in Research Articles in Applied Linguistics between English Native Writers and Iranian Writers: A Comparative Corpus-based Inquiry
}

\author{
Mehrdad Vasheghani Farahani \\ Leipzig University, Germany, Iran
}

\begin{abstract}
Metadiscourse features are the elements that can show the presence of writer(s) in the writing process. The main objective of the present study was to run a quantitative corpus-based study on the way metadiscourse features (elements) were used by English native writers and Iranian non-native writers in the field of Applied Linguistics. To this end, 29 articles in the field of Applied Linguistics written by native speakers of English and Iranian non- native speakers of English were randomly selected; compiling together a corpus of 173839 words. Also, for the raw data and corpus analysis, the Sketch engine software was exploited by the researcher. The results of the study couldreveal the fact that in overall, writers of both corpora made use of interactive metadiscourse features more than interactional metadiscourse ones and that the texts written by native speakers enjoyed more metadiscourse markers compared to texts written by Iranian nonnative speakers.
\end{abstract}

Keywords: Meta-discourse Features, Interactional Metadiscourse Features, Interactive Metadiscourse Features, Corpora, Applied Linguistics, Writing, English Native Speakers, Iranian non-native Speakers.

\section{Introduction}

Academic writing as one the four main skills has always been a very important phenomenon (Salem 2013). Indeed, academic writing has gained too much attention in the academic context and students spend time and efforts so as to master it (Jahin 2012). Academic writing is important in that it enables students to get communicative skills and competence (Al samadan and bnian 2015). In other words, the significance of academic writing lies in the fact that academic writing is "a valuable tool for communicating one's thoughts to others" (Salem 2013: 71). Widdowson (as cited in FaghihandRahimpour 2009) believes that texts are regarded as the mediating the message; therefore, writing cannot be solely regarded as the process in which students will master some vocabularies and structures, rather, it is a technique which requires instruction and practice (Yaghoubi and Ardestani 2014).

\subsection{Metadiscourse}

Owing to the fact that writing is not a neutral process, but a social engagement which requires understanding the needs and interests of the audience (Hyland 2005), one of the most important features in academic writing is the appropriate use of metadiscourse features (Cheng and Steffensen 1996). Indeed, metadiscourse "is viewed as a new approach which refers to how authors present themselves into a text and communicate with the intended addressees"(Yaghoubi and Ardestani 2014: 14).

As a matter of fact, metadiscourse features are extensively used by writers and text producers so as to make their writings more understandable, better structured for their reader ship and more interesting; consequently, it is very important to learn the appropriate use of these features in academic writing; especially in second language context. (Anwardeen et al. 2013).

The term metadiscourse or "discourse about discourse or communication about communication" (Vande Kopple 1985: 83) was first coined by the Haris in the 1950s to describe the elements and the features which are used to connect the different parts of the text (Sultan 2011). As a matter of fact, Harris (1995) coined the term metadiscourse to propose a model of understanding language(s) in everyday discourse which represents speakers' or writers' effort to direct receivers' understanding of the message. Since then, various models of metadiscourse classifications have been proposed by different researchers; helping the expansion of this "fuzzy concept" (Estaji and Vafaeimehr 2015: 38).

Metadiscourse is basically a term which is used to relate text to their contexts and help the readership to understand the texts in such a way which is suitable for the writer (Hyland, as cited in Gholami, Rafsanjani nezhad and Looragi pour 2014). Indeed, Vande Kopple (2012) mentions 3 major reasons why it is important and interesting to study metadiscourse. The first reason is that metadiscourse can reveal the structure of language and how caution a researcher has to be in analyzing those structures. In addition, metadiscourse is interesting due to the fact that in some cases, some linguistic features can occupy more than one or two metadiscoursal positions. The last, but not the least reason for analyzing metadiscourse is that in some cases, some linguistic features (metadiscourse features) can have different positions in different sentences.

Furthermore, Williams (1981: 212) defines metadiscourse simply as "writing about writing, whatever does not refer to the subject matter being addressed". According to this definition, metadiscourse is "writing about writing, whatever does not refer to the subject matter being addressed" (Harris as cited in Estaji and Vafaeimehr 2105: 38). This definition of metadiscourse entails the idea that communication is an act which is, in practice, more than the mere sharing of 
information between two or more people and "involves the personalities, attitudes, and assumptions of those who are communicating" (Haliday 2005: 3).

Since metadiscourse feature as a term which is under investigation by many researchers, it plays a critical role in discourse organizing and signaling the writers' point of view (Amiryousefi1 and Barati 2011). Metadiscourse is important in that by applying them in writing, "we can help readers recognize how our texts are organized and see exactly how different parts of them are connected to each other" (Vande Kopple 1985: 83). Moreover, according to the view that writing is a social interaction between the writer and the readership, metadiscourse directs our attention to the ways by which the writers can project themselves into their own discourse to pose their point of view towards content of the text and the readers (Hyland and Tse 2004).

Owing to the fact that metadiscourse features or "metatalk, metalanguage and metacommunication" (Vande Kopple 2012: 37)are very crucial elements in writing and composition (Cheng and Steffensen 1996), different efforts have been made to design and develop comprehensive models. Indeed, metadiscourse features are open ended in that new concepts like punctuations, typographic markers, paralinguistic cues and even the whole sentence can be added (Amiryousefi andEslami Rasekh 2010). Although the models differ to some extent, they are sequential and complete each other.

One of the earliest definitions of metadiscourse was introduced by Vande Kopple in 1985 who defines metadiscourse features as the elements by which "we can help readers recognize how our texts are organized and see exactly how different parts of them are connected to each other" (Vande Kopple 1985: 83). What is important about this definition is that it sees text at two levels. From one level, the writer provides the reader with needed information, from the other level, by using these elements, the writer will be able to interpret, organize and assess the text (ibid).

In his taxonomy, Van Kopple categories metadiscourse elements into 6 main items; namely as text connectives, code glosses, illocution markers, epistemology, attitude markers and commentary into two main categories as textual and interpersonal. While textual category is used mostly for connecting different parts of the text, the interpersonal is used when the writer expresses his feeling about a phenomenon. Vande Kopple's classificationwas significant in that it was the first effort ever made to offer a systematic, direct and comprehensive classification of metadiscourse features and could pave the way for further studies and classifications of metadiscourse features. This classification, however, has some degree of vagueness and its application was questioned by other scholars. Indeed, one major pitfall of his category is that some expressions can be classified in more than one category at the same time. As an example, citations, referring to others' statements, can be used both in validity markers and in narrators (Berkenkotter and Huckin 1995) and also provide a framework to propose a linear flow of knowledge (Hyland 2005).

Following Van Kopple's classification, "as a point of reference" (Tan, Heng andAbdullah 2012:.1), Crismore, Markkanen, and Steffensen (1993) proposed another definition and classification of metadiscourse features. At first, they proposed such other names as signaling devices, sign posts, gambits, metatalk and metacommunicative (Crismore and et al. 1993) to refer to metadiscourse concept.

As a matter of fact, they perceive metadiscourse as the elements which are used both in spoken and written medium; however, more emphasis is on written discourse. They defined their metadiscourse features as "the authors discoursing about the discourse" (Crismore 1983: 1) into two main categorizations as textual metadiscourse and interpersonal metadiscourse; each with its own subcategories. Indeed, this classification was first created based on the Vande Kopple's classification(1985) on metadiscourse; nevertheless, in order to make it more practical, less vague and more understandable, they modified, revised and made some changes in it.

In their classification, textual metadiscourse markers are composed of two subcategories. The first category, textual markers, includes such elements as logical connectives (for connecting segments of information), sequencers (used for ordering the materials), reminders (used for referring to prior content) and topicalizes (used for referring to shifts in text). The second subcategory of textual metadiscourse which is interpretive markers contains elements such as code glosses (used for explaining the texts and materials), illocutionary markers (used for naming the performed act) and announcements (used for giving information on the incoming issues).

In line with the first category, the second major category of their model is interpersonal metadiscourse markers with hedging (used to represent the lack of commitment), certainty markers (used to represent writer's commitment), attributes (used to show persuasive force), attitude markers (used to show propositional content) and commentaries (used to show the relationship between writer and reader). In comparison to Vande Kopple's classification, Crismore's categorization is more comprehensive, straight forward and detailed. Indeed, he tried to eschew from the intricacies, pitfalls, and shortcomings of Vande Kopple's categorization of metadiscourse features.

\subsection{Corpus}

Literary meant body, corpus is defined as " a collection of texts in electronic format which are processed and analyzed using software specially created for linguistic research" (Zanettin 2012 :7).In another definition, corpora are defined as "large bodies of machine- readable texts containing thousands or millions of words" (Baker 2006: 48). Indeed, a corpus is different from a randomly and ad hoc gathering of texts in a number of ways. Corpus is gathered in a systematic way which has to be representative and machine- readable (Vintar 2007; Zanettin2012). Moreover, a corpus should be compiled of texts which are authentic and which are gathered from real communication and/ or writing of people (Gajic 2010). Indeed, the aim of corpus and corpus linguistics is "to base accounts of language on corpora derived from systematic recordings of conversations and real discourse of other kinds, as opposed to examples obtained by introspection, by judgment of grammarians, or by haphazard observations" (Matthews as cited in Ahmid 2008: 60). 
Before the advent of corpora, researchers in the field of Linguistics had to rely, to a great extent, on native speakers' intuition or introspection; they could, however, describe what people can understand from their language rather than how it works (Tsui 2004). With the introduction of corpus into language studies in the 1950s, researchers could, in a systematic way, find the way languages work and how people use language in real context. The corpora are used extensively in language studies in a way that "enthusiasm for the pedagogic possibilities of corpora has been steadily growing in the last few years" (Mauranen 2004: 889). Corpora are used not only in empirical research for investigating the patterns real language use, but also for compiling dictionaries (like Cobuild English Language Dictionary) and grammar books (like Comprehensive grammar of English Language) (Anderman andRogers 2006).

Corpora as a methodology or as research tools (Serpollet 2008) are very useful instrumentations for language studies. Indeed, from the 1980s "Corpus Linguistics has developed at an ever accelerating rate" (Mcenery and Xiao 2006: 18). They have been used by researchers in different aspects of language studies including teaching English as a foreign language (see for example Nesselhauf 2004; Tanko 2004 and Byrnes 2006) and Translation Studies (see for example Frankenberg-Garcia and Guo-rong 2010; Awal and et al. 2014). Corpora have also been used in lexicography (see for example Prinslooand Gouws 2008;Zainudin and et al. 2014) and in collocation analysis (see for example Dias and et al. 2005; Uka2005 and Čermák 2005); however, when it comes to metadiscourse features, there is a paucity of the application of corpus-based tools.

\section{Review of the Related Literature}

Metadiscourse features have been under investigations by many researchers who have pointed to the usage of these features in academic writing. For having an account of these studies and in order to broaden the scope of the current research, it is necessary to have a critical look on some of the related researches. It is worth mentioning that most studies in the domain of metadiscourse features have been deprived of using corpus software; as a result, the validity of the initial data is questionable.

In a comparative study on the way metadiscourse are used and distributed in English and Persian,Zarei and Mansoori (2011) embarked on a study. In this study, they applied Hyland and Tese (2004) classification of metadiscourse features in two languages. Their corpus was restricted to 5 research articles in English and 5 research articles in Persian in the field of Computer Engineering. The findings of the study suggested that the Persian articles, as compared to English ones, contained more metadiscourse features in terms of interactive classification; while English writers relied more on the interactional ones.

In one case of study, Ahangari and Kazemi (2014) applied Hyland's classification of metadiscourse features in analyzing Alice in Wonderland novel. The results of this case study reported that in case of interactional metadiscourse features, the most prevalent category belonged to attitude markers, followed by boosters and self-mentions. As far as the interactive metadiscourse features were concerned, the obtained results showed that code glosses enjoyed the highest frequency followed by endophoric and transition markers. Also, the findings indicated that overall the interactional metadiscourse features have been used more by the writer in comparison to the interactive metadiscourse features.

In line with this study, Poorfeshani and et al. (2012) conducted a study on the way metadiscourse features are used in research articles of Applied Linguistics and Engineering by native speakers of English and Iranian writers. After randomly selecting eight articles in Applied Linguistics and eight articles in Engineering, they exploited Hyland's metadiscourse features as their theoretical framework. The results of this study demonstrated that in terms of interactive metadiscourse features, logical markers were used more in both disciplines; while as far as the interactional metadiscourse was concerned, the Applied Linguistics writers used more attitude markers and the engineering writers used hedging more. More, the results of the chi-square test could reveal that overall, the writers in the field of engineering used more metadiscourse features than writers in Applied Linguistics.

As a case in point, Anwarden and etal (2013) conducted a corpus-based study on the usage and distribution of metadiscourse features in argumentative writing of Malaysian Tertiary students. Using Hyland's and Hyland and Tse's classification of metadiscourse feature, they analyzed Malaysian corpus of students' argumentative writing (MCSAW) by using Word Smith software. This study revealed that subjects used textual discourse markers more than interpersonal ones which could mean that Malaysian students are not able to use interpersonal discourse markers in their argumentative writing.

In a similar vein, interactive and interactional metadiscourse features in conclusion sections of master theses in English discipline were analyzed by Rezaei and et al. (2015). Their theoretical framework was Hylland's classification of metadiscourse features and their data consisted of 30 master theses in Teaching, Literature and Translation disciplines. Indeed, they were to see if there were any statistically significant differences between these disciplines in terms of using metadiscourse features. The results revealed that while in all disciplines, transitions were the most used discourse markers.

\section{Research Question}

As far as the present study is concerned and in line with the above- mentioned points, the following research questions are addressed. It is worth mentioning that since the study in hand is a descriptive, nonexperimental and quantitative research in nature, there is no hypothesis.

R.Q 1: How were Interactive Metadiscourse features used and distributed in English native writers' research papers? 
R.Q 2: How were Interactive Metadiscourse features used and distributed in Iranian non-native writers' research papers?

R.Q 3: How were Interactional Metadiscourse features used and distributed in English native writers' research papers?

R.Q 4: How were Interactional Metadiscourse features used and distributed in Iranian non- native writers' research papers?

R.Q 5: Are there any statistically significant differences between the way Interactive Metadiscourse features were used and distributed in English native writers' and Iranian non- native writers' research papers?

R.Q 6: Are there any statistically significant differences between the way Interactional Metadiscourse features have been used and distributed in English native writers' and Iranian non- native writers' research papers?

\section{Methodologyand Instrumentation}

In order to put this study into the operation phase, a number of different instrumentations were exploited and some steps were taken. As far as the theoretical framework is concerned, the current research enjoys the metadiscourse classification provided by Hyland (2005). He classifies metadiscourse features into two main categories as interactive and interactional. These two main calcifications are borrowed from Thompson and Thetela's (1995) resources to interact between writer and reader.As for the interactive category, the interactive category is used mainly to make a connection between writer's understating of the receiver. In other words, interactive is "concerns the writer's awareness of a participating audience and the ways he or she seeks to accommodate its probable knowledge" (Hyland 2005: 48). On the other side, the interactional metadiscourse features category is mostly used when the writer wants to make interaction. Indeed, "the writer's goal here is to make his or her views explicit and to involve radars by following them to respond to the unfolding text $\ldots$ and includes the ways he or she conveys judgments" (ibid).

The main reasons for applying this category for the present study are multifarious. One reason is that this model is the most up-to date classification of metadiscourse features. Also, this model is comprehensive in a sense that it includes most of the features (Ghadyani\&Tahririan; 2015). The last, but not the least reason is that this model is very straightforward and is not complicated like other classifications (Abdi and et al. 2010).

Table1 :A Classification of metadiscourse features (Hyland 2005)

\begin{tabular}{|c|c|c|}
\hline Category & Function & Example \\
\hline Interactive & $\begin{array}{l}\text { Help to guide the reader } \\
\text { through the text }\end{array}$ & Resources \\
\hline Transitions & $\begin{array}{l}\text { Express relations between } \\
\text { main clauses }\end{array}$ & In addition; but; thus; and \\
\hline Frame markers & $\begin{array}{l}\text { Refer to discourse acts, } \\
\text { sequences and stages }\end{array}$ & $\begin{array}{l}\text { Finally; to conclude; my } \\
\text { purpose is }\end{array}$ \\
\hline Endophoric markers & $\begin{array}{l}\text { Refer to information in other } \\
\text { parts of the text }\end{array}$ & $\begin{array}{l}\text { Noted above; see figure; in } \\
\text { section } 2\end{array}$ \\
\hline Evidentials & $\begin{array}{l}\text { Refer to information from } \\
\text { other }\end{array}$ & $\begin{array}{l}\text { texts According to } \mathrm{X} ; \mathrm{Z} \\
\text { states }\end{array}$ \\
\hline Code glosses & $\begin{array}{l}\text { Elaborate propositional } \\
\text { meaning }\end{array}$ & $\begin{array}{l}\text { namely; e.g.; such as; in } \\
\text { other words, }\end{array}$ \\
\hline Interactional & Involve the reader in the text & Resources \\
\hline Hedges & $\begin{array}{l}\text { Withhold commitment and } \\
\text { open dialogue }\end{array}$ & $\begin{array}{l}\text { Might; perhaps; possible; } \\
\text { about }\end{array}$ \\
\hline Boosters & $\begin{array}{l}\text { Emphasize certainty and } \\
\text { close dialogue }\end{array}$ & $\begin{array}{l}\text { in fact, /definitely/it is clear } \\
\text { that }\end{array}$ \\
\hline
\end{tabular}




\begin{tabular}{|l|l|l|}
\hline Attitude markers & $\begin{array}{l}\text { Express writer's attitude to } \\
\text { proposition }\end{array}$ & $\begin{array}{l}\text { Unfortunately; I agree; } \\
\text { surprisingly }\end{array}$ \\
\hline Self-mentions & Explicit reference to authors & I; we; my; me; our \\
\hline Engagement markers & $\begin{array}{l}\text { Explicitly build relationship } \\
\text { with reader }\end{array}$ & $\begin{array}{l}\text { Consider; note; you can see } \\
\text { that }\end{array}$ \\
\hline
\end{tabular}

\subsection{Corpus of the Study}

For the purpose of this study, a "Do IT Yourself" or "DIY" corpus was exploited. Also known as disposable corpus, DIY corpus is defined as "a collection of internet documents or more precisely web pages in HTML format created ad hoc as a response to a specific text to be translated, which is an open and disposable corpus" (Zanettin, as cited in Mahadi and et al. 2010: 15). For this purpose, 11 papers in the field of Applied Linguistics which had been written by native speakers of English and 18 papers which had been written by Iranian non-native of English were randomly selected. Altogether, 29 articles, in the academic and scientific genre (Applied Linguistics) were selected to meet the criteria of representativeness of the corpus. They were randomly selected so as to avoid the idiosyncrasies of the writers and as Bowker and Pearson (2002:49) say, it is better to gather "greater number of texts written by different authors, rather than just a few texts written by only one or two different authors". The reason why the number of papers differs is due to the fact that they did not have an equivalent number of words, therefore, efforts were made to compile a corpus which was, to a great extent, equivalent in terms of word number. Both American and British English styles were included in writings. Since the present study was a corpus-based research, there was a need to use data which could be read by corpus software. To this end, all the texts were, first, rendered into text files so that the corpus software could read them. It is necessary to point to the fact that except for the bibliographic information and references, all parts of the papers were included in the study. The bibliographic information and references were deleted because they could not contain any examples of metadiscourse features.

Table2: Basic corpus information

Name of the Corpus Number of Words Number of Tokens $\begin{aligned} & \text { Number } \\ & \text { sentences }\end{aligned}$ of

\begin{tabular}{lccc}
\hline Non-Native Writers & 85961 & 106987 & 3303 \\
Native Writers & 87878 & 111438 & 3006
\end{tabular}

Total

173839

281425

\subsection{Corpus Software}

As the title of the paper in hand suggests, this research was a corpus-based inquiry. As a result, it was necessary to exploit a corpus software. Indeed, from among the various software available in the market, the study in hand, applied "Sketch Engine" software which is free for Leipzig University Students (including the corresponding writer) and which is available for trail usage. In fact, Sketch Engine is a windows-oriented and supported corpus software which since its first launch in 2003, has been used in various projects, including dictionary compiling and text analysis. This program was designed by Lexical Computing Ltd. (https://www.sketchengine.co.uk/). Apart from financial issues, this software is very user-friendly and can provide the researchers with the opportunity to have access to a wide range of raw data from various corpora in different languages like National British Corpus, Early English Books Online, English Web 2013 and ... (McGillivray and Kilgarrif, 2013). 


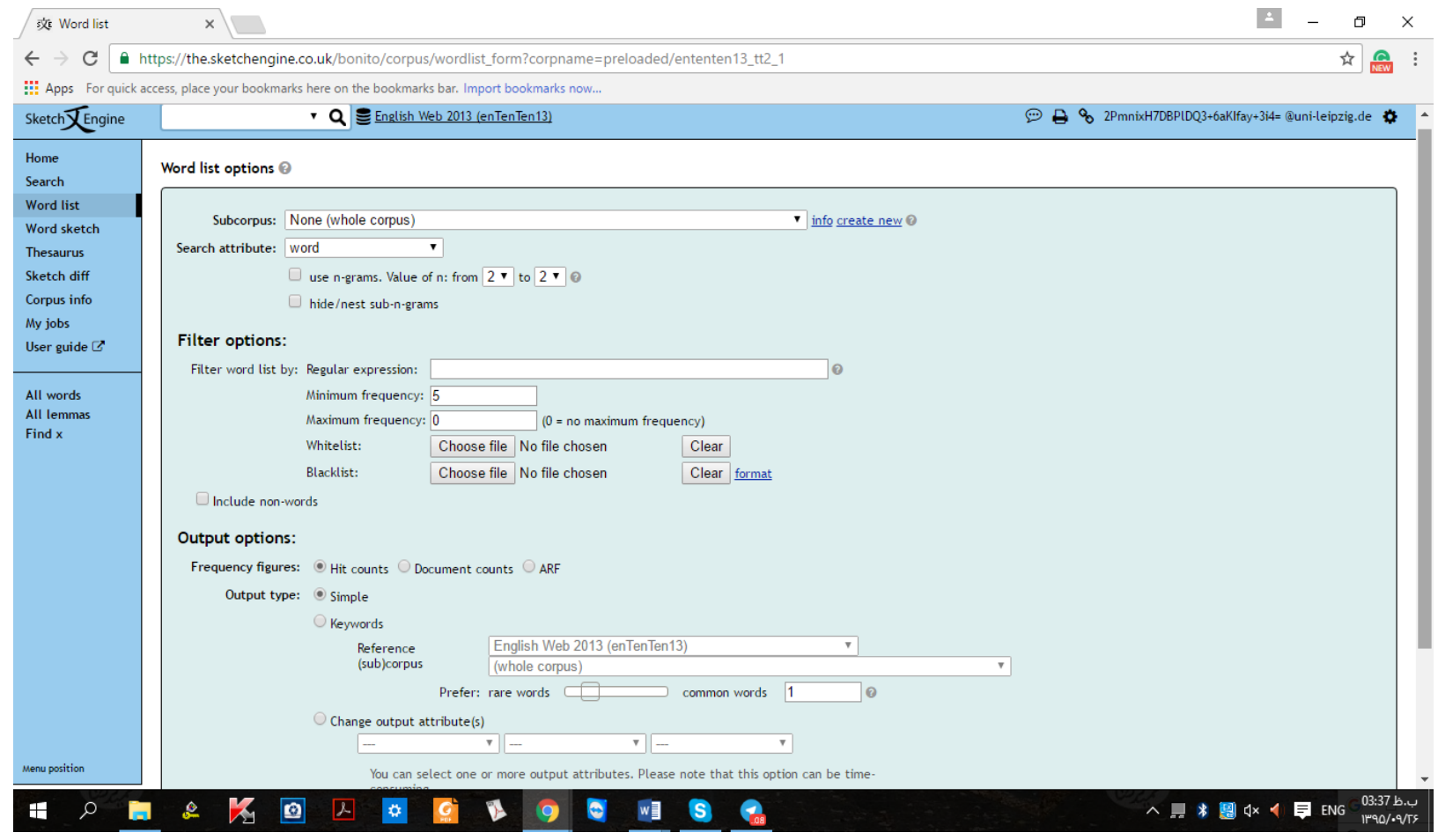

Figure 1: A basic screenshot of Sketch Engine software

\section{Examples of Metadiscourse features in English Native Authors}

For making the results of the study more tangible, it was found necessary to give some examples of the content analysis of both corpora. For this purpose, the concordance lines of both interactive and interactional metadiscourse features were presented.

\subsection{Interactive Metadiscourse Features}

\begin{tabular}{|c|c|c|c|}
\hline $\begin{array}{l}\text { file496862. } \\
\text {.. }\end{array}$ & $\begin{array}{r}\text { include students from mixed L1 } \\
\text { backgrounds; }\end{array}$ & thus & $\begin{array}{l}\text {, the extent to which learners share } \\
\text { difficulties }\end{array}$ \\
\hline $\begin{array}{l}\text { file496862. } \\
\text {-. }\end{array}$ & $\begin{array}{r}\text { singletons, final singletons, or final } \\
\text { clusters. }\end{array}$ & Thus & , there were some clear parallels between \\
\hline $\begin{array}{l}\text { file496862. } \\
\text {.. }\end{array}$ & $\begin{array}{r}\text { on which the MA group scored } 4 \% \\
\text { overall. }\end{array}$ & Thus & , almost all MA speakers could potentially \\
\hline file496862. & teachers are ill-prepared to do so. & Thus & , we concur with Levis (2007), that there \\
\hline
\end{tabular}

Figure 2: An example of concordance line of the word "thus" in transition category

file496862.. .

file496862..

file496862..

file496862.. .

file496862.. accordance with sound pedagogical principles. 6 and phonetic perception. They retail his Fathman and Precup (1983) came to similar implicit language learning mechanisms. His cor instruction Before moving to some general
Conclusion
s conclusion that the $\mathrm{CP}$ for phonetics/phonology ends conclusion in studies of immigrants acquiring English conclusion, as communicated in a recent conference conclusion, perhaps I may be permitted a brief s excursion 
file496862.. $\quad$ have simply explored its manifoldness. My conclusion from this exploration is that the $\mathrm{CPH}$ can

file496862.. $\quad$ psychologist Ross Thompson arrived at the

. $\quad$ following

conclusion about the CP concept. While the metaphor

file496862.. unpredictable. Fitzpatrick acknowledges that conclusion

.

broad $\mathbf{s}$

cannot be drawn from case study data and

file496862.. $\quad$ strategies when dealing with online information. Conclusion The discussion arising from the use of

Figure 3:An example of concordance line of the word "conclusion" in frame marker category

\begin{tabular}{|c|c|c|c|}
\hline $\begin{array}{l}\text { file496862. } \\
. .\end{array}$ & $\begin{array}{r}\text { individual speakers at each observation } \\
\text { point. ( }\end{array}$ & See & Figures 1a-1d.) Kruskal Wallis tests were \\
\hline $\begin{array}{l}\text { file496862. } \\
\text {.. }\end{array}$ & 011 and at $T 7, x^{2}(1)=5.14, p=.023$ & See & Figures 1a-1d.) All other between-group \\
\hline $\begin{array}{l}\text { file496862. } \\
\text {.. }\end{array}$ & study - even at T2 in several instances, as & seen & in Table 1. Moreover, on 3 additional onsets \\
\hline $\begin{array}{l}\text { file496862. } \\
\text {.. }\end{array}$ & the poorest performance on any target was & seen & by the MA speakers on /ld/ codas. Only \\
\hline $\begin{array}{l}\text { file496862. } \\
. .\end{array}$ & $\begin{array}{r}\text { targets improved, } 5 \text { in each language } \\
\text { group }\end{array}$ & see & Table 2). On 2 target codas, /st/ and / \\
\hline $\begin{array}{l}\text { file496862. } \\
\text {.. }\end{array}$ & the "wow-factor" (Murray and Barnes 1998; & see & $\begin{array}{l}\text { also Witte 2007). In particular, the } \\
\text { development }\end{array}$ \\
\hline $\begin{array}{l}\text { file496862. } \\
\text {-. }\end{array}$ & require guidance either from research ( & see & Neri et al. 2006) or from a teacher who \\
\hline $\begin{array}{l}\text { file496862. } \\
. .\end{array}$ & specific capacities or behaviors. We shall & see & $\begin{array}{l}\text { that the precise termini proposed for } \\
\text { maturational }\end{array}$ \\
\hline $\begin{array}{l}\text { file496862. } \\
\text {.. }\end{array}$ & $\begin{array}{r}\text { affected by such constraints. We shall } \\
\text { further }\end{array}$ & see & That researcher diverge markedly in respect \\
\hline
\end{tabular}

Figure 4:An example of concordance line of the word "see" in endophoric marker category

\begin{tabular}{|c|c|c|c|}
\hline file496862.. & least one high functional load pair $(\mathrm{H})$, & according & toCatford's (1987) hierarchy. No particular \\
\hline file496862.. & Frequencies of scores on the 21 target items & according & $\begin{array}{l}\text { to speaker group Score Range Count } \\
\text { Mandarin }\end{array}$ \\
\hline file496862.. & verbal analytical ability, an ability which, & according & to him, played no role in the performance \\
\hline file496862.. & $\begin{array}{r}\text { acceptance (or be in the process of } \\
\text { nativization, }\end{array}$ & according & to the third stage of Schneider's model \\
\hline file496862.. & locations included in the corpus, grouped & according & to administrative districts. The estimated \\
\hline file496862.. & unlikely candidates for indigenization, & according & toBamgbos.e's (1998) criteria. Structural \\
\hline file496862.. & tða=2; mPsb, with the upper parameters, & according & to $b$ i bound for the degrees of freedom \\
\hline file496862.. & reported as significantly different from zero & ing $->$ & four multinle rec \\
\hline
\end{tabular}


file496862..

file496862.. . of images from a database, arranges them

Confirmatory analyses should be performed according to her experimental design, and proceeds

according to a principled plan guided by theoretical

Figure 5:An example of concordance line of the word "see" in evidentials category

file496862...

file496862...

file496862... emphasized over low functional load distinctions

file496862... not on the sources of learner difficulties

file496862...

rare or occur only in very uncommon words,

ESL learners, high functional load pairs

third author and used in previous studies, such $/ \mathrm{mw} /$ as in moire, $/ \mathrm{tm} /$ as in tmesis, or

such initial $/ \mathrm{d} / \mathrm{-} / \mathrm{/} / \mathrm{s}$ should be emphasized
as

such as

such
as

such Munro and Derwing (2008). In that investigation
as

Figure 6: An example of concordance line of the word "such as" in code glosses category.

\subsection{Interactional Metadiscourse Features}

file496862... 2001; Macdonald 2002), such that teachers may be almost as overwhelmed as their students

file496862... $\quad$ the extent to which learners share difficulties may be minimal. Second, empirical evidence file496862... initially, struggle with a given segment may acquire the phone relatively quickly without file496862... Iongitudinal research on acquisition. This study may therefore add to the scant body of longitudinal file496862... of learners in a mixed L1 classroom, it may be helpful to establish common areas of file496862... $\quad$ speakers a L1-based instructional strategy may be justifiable. For those that do not, file496862... that the learners encountered at that point may have been due to a lack Figure 7:An example of concordance line of the word "may" in hedges category

file496862... aspects of prosody, and articulatory settings. $\begin{gathered}\text { In } \\ \text { fact }\end{gathered}$, the actual number of pronunciation issues file496862... $\quad$ strongly influence instruction practices; $\underset{\text { fact }}{\text { in }}$, it is often materials developers who decide file496862... learning a handful of individual speech sounds. $\begin{gathered}\text { In } \\ \text { fact }\end{gathered}$, L2 segmental acquisition has been shown file496862... $\quad$ used to elicit /ld/ in the present study. $\underset{\text { fact }}{\text { In }}$, Munro and Derwing (2008) reported such

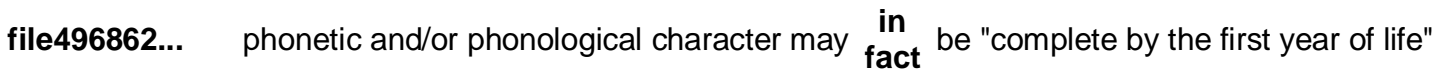
file496862... $\quad$ translation he now believed to be correct was $\underset{\text { fact }}{\text { in }}$ so. He stated he would not have done this file496862... that an experimenter could investigate. $\underset{\text { fact }}{\text { In }}$, two core principles of the structure of file496862... $\quad$ F-distributions do not apply in such cases. In , the pivotal quantities for such hypothesis 
Figure 8:An example of concordance line of the word "in fact" in hedges category

file496862... over time, making adjustments as needed. Unfortunately , current evidence indicates that many teachers

file496862... $\quad$ the L2 or could be supported by the L1. Unfortunately , Oxford's classifications are less than

file496862... to a large selection of real data sets. Unfortunately , in real experiments the true generative

file496862... treatment effects (a misconception that is unfortunately rather common at present). In psycholinguistics

file496862... to converge It is altogether possible and unfortunately common that the estimation procedure for

Figure 9: An example of concordance line of the word "unfortunately" in hedges category

file496862... T6G 0Z1. E-mail: tderwing@ualberta.ca Ron I . Thomson: Department of Applied Linguistics

file496862... $\quad$ target words in the following frame: "Now I say " An aural repetition task was

file496862... moving to some general conclusions, perhaps I may be permitted a brief excursion into

file496862... 1997; Palmen, Bongaerts and Schils 1997). I have simply explored its manifoldness.

file496862... $\quad$ try' from item statements. For example, ' I try to listen to other people's conversations

file496862... $\quad$ conversations in English' was changed to ' I listen to other people's conversations

Figure 10: An example of concordance line of the word "I" in self-mentions category

file496862...

Praat (Boersma and Weenink 2011), but noted these resources tend not to be teacherhave that friendly

file496862... only up to this age. On the other hand, he the twelfth month of infancy. It might be

file496862...

file496862...

file496862...

by Pulvermüller and Schumann (1994), who different line. Thus Johnson and Newport note

(1989) that notes
that

noted
that

note, as the brain matures, the axons of that neurons

the crucial measure in their study was

file496862..

Dörnyei, 2003). Strategies Bialystok (1983)

notes the disparity exists regarding what

that constitutes

file496862...

the final column lists the by-observation Note

noise. that

in this example we did not include by-item

Figure 11:An example of concordance line of the word "note that" in Engagement markers category.

\section{Data Analysis}

In order to answer the research questions of the study, it was necessary to run the statistical analysis of the collected data. For doing so, SPSS statistical software was exploited and the frequency of the metadiscourse features was calculated.

Table 3: Interactive metadiscourse features written by native authors

$\begin{array}{ccc}\text { Transitions } & 3417(71.6) & \text { P-value } \\ \text { Frame markers } & 875(18.3) & \end{array}$




$\begin{array}{cc}\text { Endophoric Markers } & 228(4.8) \\ \text { Evidentials } & 14(0.3) \\ \text { Code Glosses } & 240(5) \\ \text { total } & 4774(100)\end{array}$

Table 3 demonstrates the frequency and mode distribution of the interactive metadiscourse features used by native authors in the corpus. As can be seen, the total number of interactive metadiscourse features were 4774 counts out of which $71 \%$ (3417) were dedicated to transitions as the most frequent interactive metadiscourse features. After that frame markers with 875 counts $(18 \%)$ were the second most used interactive metadiscourse features used by native writers. In this regard, the third most frequent interactive metadiscourse features exploited by native speakers was code glosses with 240 counts (5\%). However, the least used applied interactive metadiscourse features enjoyed by native speakers were endophoric markers and evidentials with $4.8 \%$ and $0.3 \%$; respectively.

Table 4: Interactional metadiscourse features written by native authors

$\begin{array}{ccc}\text { Hedges } & 990(39.3) & \text { P-value } \\ \text { Boosters } & 636(25.2) & \\ \text { Attitude Markers } & 111(4.5) & <0.001 \\ \text { Self-mentions } & 732(29) & \\ \text { Engagement Markers } & 51(2) & \\ \text { total } & 2520(100) & \end{array}$

Table 4 represents the way interactional features were used and distributed in papers written by foreign authors. Ac can be seen, the total number of interactionl metadiscourse features by native writers was 2520 counts out of which 990 items (39.3\%) were dedicated to hedges as the most frequent one. With more than 732 counts (29\%), self-mentions were the second most enjoyable interactional metadiscourse features distributed in texts written by native authors. After that boosters with 636 counts $(25.2 \%)$ were the third most frequent interactional metadiscourse features used by native speakers followed by attitude markers as the fourth most frequent interactional metadiscourse features. However, when it comes to the least applicable interactional metadiscourse feature, engagement markers with 51 counts (2\%) were the last used one in the category.

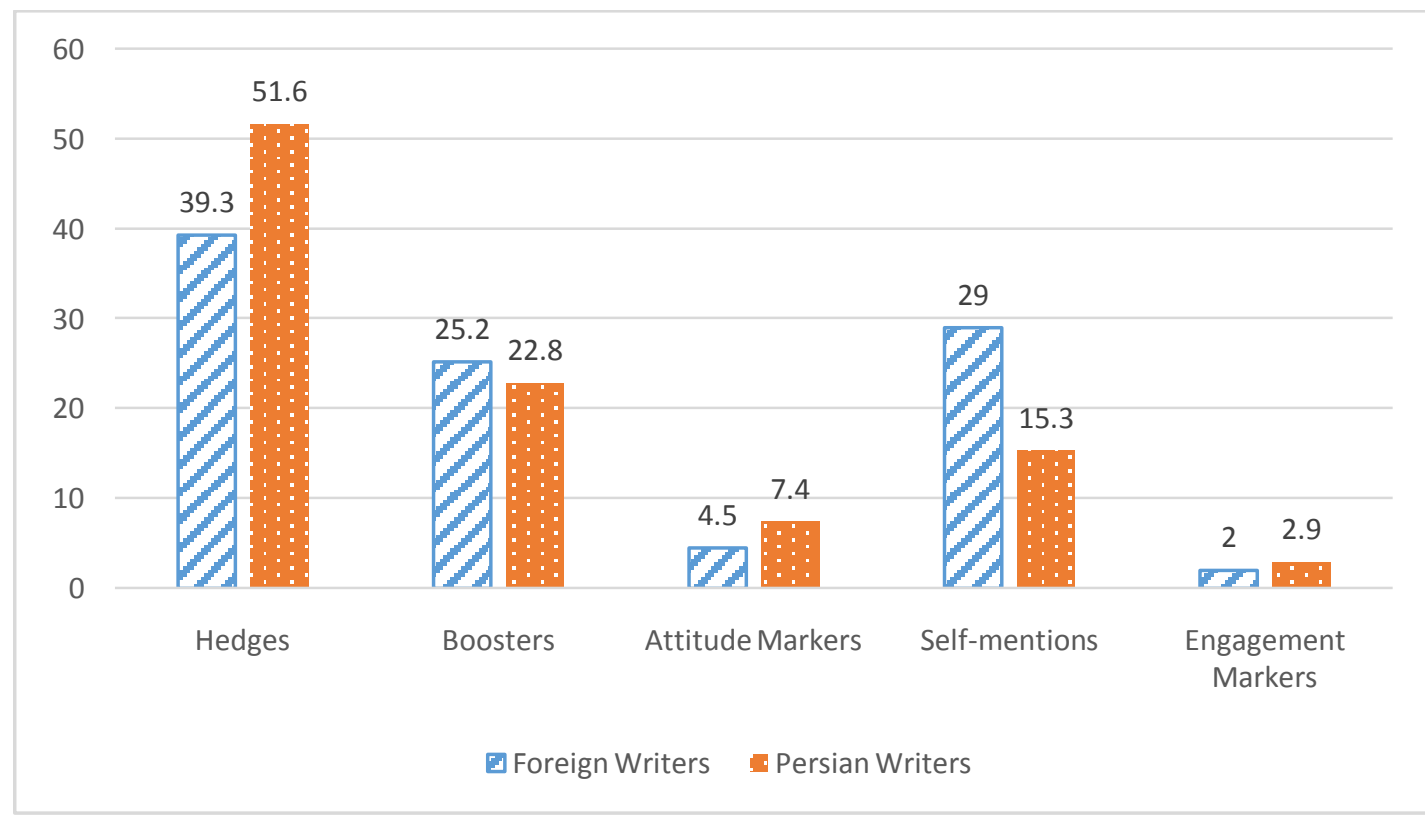

Figure 12: The bar graph of the distribution of interactional metadiscourse features in both corpora 
Table 5:Interactive metadiscourse features written by non- Native authors

$\begin{array}{ccc}\text { Transitions } & 2768(69.9) & \text { P-value } \\ \text { Frame markers } & 720(18.2) & \\ \text { Endophoric Markers } & 49(1.2) & <0.001 \\ \text { Evidentials } & 130(3.3) & \\ \text { Code Glosses } & 291(7.4) & \\ \text { total } & 3958(100) & \end{array}$

Table 5 indicates the way interactive metadiscourse features were distributed and used by non-native authors. As it is conspicuous, the total number of interactive metadiscourse features used by non-native authors was 3958 counts out of which 2768 counts $(69 \%)$ were dedicated to transitions as the most frequent metadiscourse followed by frame markers with 720 counts (18\%) as the second most frequent metadiscourse markers used by mon-native authors. After that code glosses with only 291 counts $(7.4 \%)$ were the third most frequent interactive metadiscourse markers applied by non-native authors. evidentials with 130 counts $(3.3 \%)$ were the fourth most frequent metadiscourse features. Finally, endophoric markers with 49 counts (1.2\%) were the least used applied interactive metadiscourse features use by non-native authors.

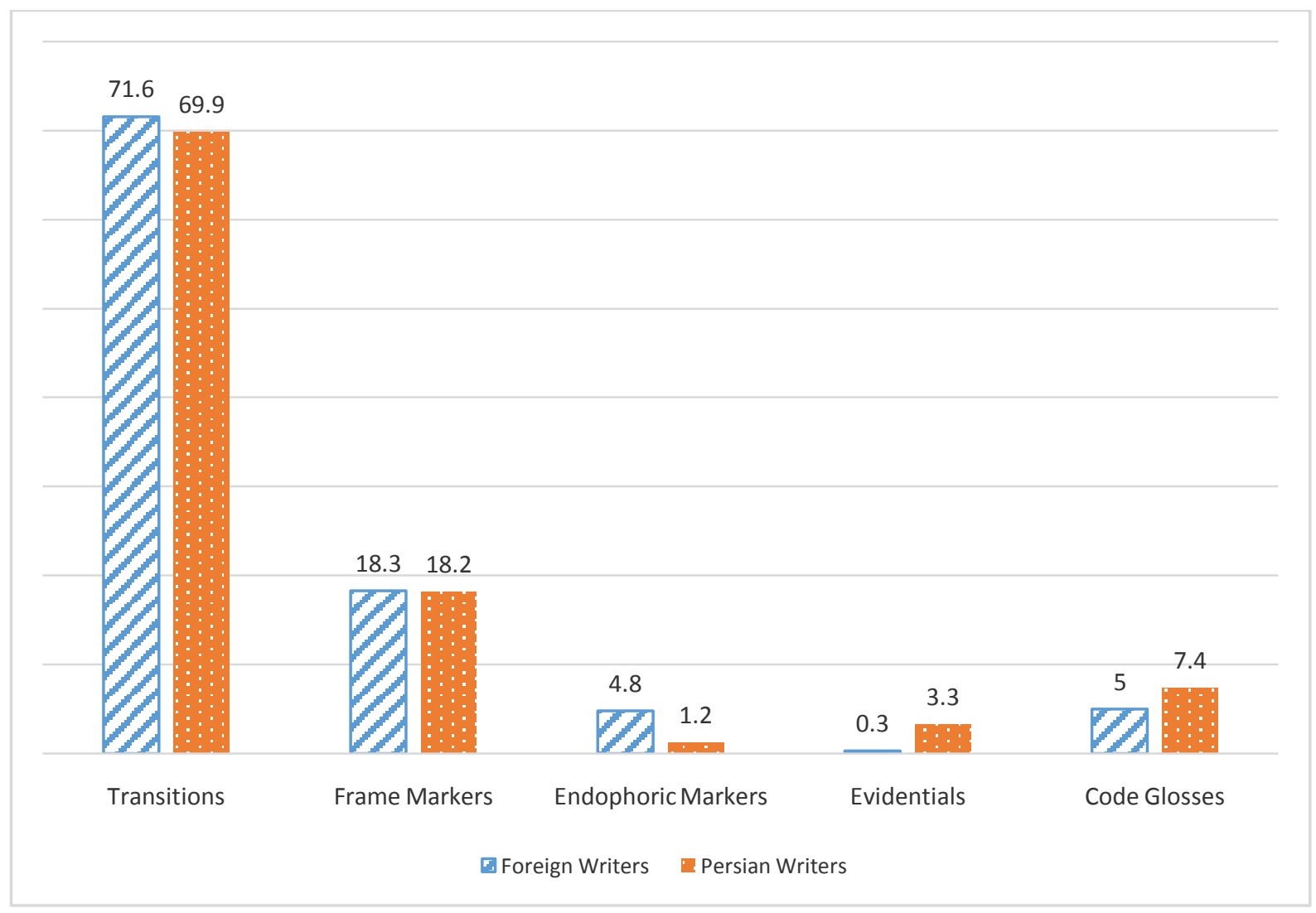

Figure 13 : The bar graph of the distribution of interactive metadiscourse features in both corpora. 
Table 6: Interactional metadiscourse features written by non-Native authors

\begin{tabular}{ccc}
\hline Hedges & $929(51.6)$ & P-value \\
Boosters & $411(22.8)$ & \\
Attitude Markers & $134(7.4)$ & \\
Self-mentions & $275(15.3)$ & \\
Engagement Markers & $52(2.9)$ & \\
total & $1801(100)$ & \\
& & \\
\hline
\end{tabular}

Table 6 shows the way interactional metadiscourse features were used and distributed in texts written by nonnative authors. As it is evident, the total number of interactive metadiscourse features used by bon-native authors was 1801 counts out of which 51\% (929 counts) were dedicated to hedges as the most frequent interactive metadiscourse features. In the second place were boosters as the most frequent interactive metadiscourse features applied by non-native authors (411 counts). Self-mentions with 275 counts (15\%) of the total were the third most frequent interactive metadiscourse features. Attitude markers with 134 counts $(7 \%)$ were the fourth frequent interactive metadiscourse features used by non-native authors. The least enjoyable interactive metadiscourse features used by non-native authors were engagement markers with 52 counts $(2.9 \%)$.

Table7: Results of the Chi-Square test in interactive met discourse features

\begin{tabular}{cccc}
\hline & Value & df & Asymp. Sig. (2-sided) \\
Pearson Chi-Square $222.869^{\mathrm{a}}$ & 4 & .000 \\
Likelihood Ratio 245.103 & 4 & .000 \\
Linear-by-Linear Association 23.206 & 1 & .000 \\
N of Valid Cases 8732 & & \\
\hline
\end{tabular}

\section{a. 0 cells $(.0 \%)$ have expected count less than 5 . The} minimum expected count is 65.27 .

In order to analyze any statistically significant differences between the way interactive metadiscourse features were distributed a chi-square test was conducted. As the data in table 7 can provethe P.value of the Pearson Chi-Square is significant above $0.05(<0.001)$ and there is a significant difference between the distribution of the interactive metadiscourse features in both corpora.

Table 8: Results of the Chi-Square test in interactional metadiscourse features

\section{Chi-Square Tests}

Value $\quad$ df $\quad$ Asymp. Sig. (2-sided)

$\begin{array}{rrrr}\text { Pearson Chi-Square } & 144.211^{\mathrm{a}} & 4 & .000 \\ \text { Likelihood Ratio } & 147.823 & 4 & .000 \\ \text { Linear-by-Linear Association } & 75.706 & 1 & .000\end{array}$




\section{a. 0 cells $(.0 \%)$ have expected count less than 5 . The minimum expected count is 65.27 .}

The same statistical analysis was conducted in the way interactional metadiscourse features were used and distributed in both corpora. As the data in table 8 can demonstrate, P.value of the Pearson Chi-Square is significant above $0.05(<0.001)$ and there is a significant difference between the distribution of the interactional metadiscourse features in both corpora.

\section{Discussions}

\subsection{Response to the First and Second Research Questions}

The first and second research questions of the study were aimed to analyze the way interactive metadiscourse features were distributed and used in texts written by native speakers of and Iranian non- native English speakers. To this end, the interactive metadiscourse features written by native speakers and by Iranian non- native speakers were analyzed separately. As the statistics in tables 3 and table 5 showed, the texts written by English native writers had 4774 interactive metadiscourse features as opposed to 3958 counts in texts written by Iranian non-native authors. In addition, from among the interactive metadiscourse features in both corpora, transitions were the most frequent ones enjoyed by the authors in both corpora authors. However, the English native writers used more transitions than the Iranian ones. In the second rank, were frame markers with 875 counts in texts written by foreign authors as compared to 720 counts in texts written by Iranian authors. Like transitions, the native authors applied more frame markers in comparison to Iranian writers.

As far as the code glossed were concerned, both writers used this interactive metadiscourse feature as the third most frequent one; however, the Iranian authors applied more than the native authors (291 and 240; respectively). While English native writers used endophoric markers (228 items) as the fourth most applicable interactive metadiscourse feature, the Iranian non-native authors made used of evidentials (130) as the fourth most used interactive metadiscourse features. In the same line, the native writers used evidentials as the least used interactive metadiscourse features (14 items), while Iranian writers used endophoric markers as the least used interactive metadiscourse markers.

The data in tables 3 and 5 can add support to this notion that generally the foreign writers benefited from interactive metadiscourse features more than the Iranian Non-native authors. The more reliance of native authors on interactive metadiscourse features indicate that they were more concerned to shape their texts in such a way that the needs of the particular readership are met and that the authors were well aware of participating the audience in the process of text production.

\subsection{Response to the Third and Fourth Research Questions}

The third and fourth research questions were mainly concerned with the way interactional metadiscourse features were used and distributed in texts written by English native and Iranian non-native authors. For this purpose, the interactional metadiscourse features were analyzed in both corpora. As the data in tables 4 and 6 can show, the native authors used more interactional metadiscourse features in comparisons to the Iranian non- native ones (2520 vs. 1801). In this regard, the first most used interactional metadiscourse feature used in both corpora were hedges with 900 and 929 items, respectively. However, when it comes to the second place, the corpora differ. In other words, while selfmentions(732 items) were the second most used interactional metadiscourse features in texts written by English native authors, in texts written by Iranian non-native authors, boosters were the second most applicable interactional metadiscourse features (411 items). While, boosters with 636 items were the third most applicable interactional metadiscourse features in texts written by English native authors, self- mentions with 275 counts were the third most frequent interactional metadiscourse features in texts written by Iranian non-native speakers. Attitude markers were the fourth most used interactional metadiscourse markers used by authors in both corpora (111 and 134 , respectively).Engagement markers were the least used interactional metadiscourse features in both corpora (51 and 52 respectively).

As the data in tables 4 and 6 can show, native speakers used more interactional metadiscourse features as compared to Iranian non-native authors. This trend can support the idea that native speakers were more familiar with the way to make their texts read in such a way that their ideas and beliefs seem to be more explicit and more well-established as this is the main function of the interactional metadiscourse features.

\subsection{Response to the Fifth and Sixth Research Questions}

The last questions of this study dealt with the way interactive and interactional metadiscourse features were used and distributed in both corpora. To this end, a chi- square test was conducted for both corpora. As the data in table 7 and 8 can represent, the P.value was bigger than 0.05; as a result, there was a significant difference between the way interactive metadiscourse features were used and distributed in both corpora. Also as the P.value was bigger than bigger than 0.05 ; there was a statistically significant difference between the way interactional metadiscourse features were used and distributed in texts written by English native speakers and Iranian non-native speakers.

The results of this study are in line with the studies done by other researchers. Eghtesadi and avidinia (2009) found that native speakers usually use more metadiscourse markers in comparison to Iranian non-native writers. Rezaei and Mansoori (2011) who did a study on discourse markers in humanities and non- humanities by English and Persian writers support the findings of this study. They found that interactive metadiscourse features were used more than 
interactional ones.Also, the study did by Vaez Dalili and Dastjerdi (2013) who studied discourse markers in media discourse used by native speakers and non-native speakers of English demonstrated that native speakers use more discourse markers as compared to non-native writer. Sara and Ghonsooly (2015) found that generally naïve speakers of English apply more interactive and interactional metadiscourse features as compared to Iranian non-native authors.

The results, however, are in contradictory to the results obtained from other studies. Kuhi and Mojood (2012) found that compared to interactive metadiscourse markers, interactional metadiscourse markers were used more than interactive ones used in English and Persian editorials. Furthermore, Rezaei Zadeh and Baharlooei (2015) found out that in thesis writing, interactional metadiscourse features were used significantly more than that of the interactive ones.

\section{Concluding Marks}

Metadiscourse features are very open-ended category which can be analyzed from various perspectives. The results of this study showed that metadiscourse features are very important features in the complex process of writing. In addition, in general, the native speakers of English used more metadiscourse features than the Iranian non-native authors. This can be due to the fact that since English their mother tongue, they are more aware of the logic and the mode of using these expressions. Also, this may be due to their educational backgrounds; meaning that they are in such a level of literacy that they know how to organize their texts.

Both corpora, English and Persian, made use of interactive more than the interactional metadiscourse features; meaning that, the authors made efforts to shape their texts in such a way that it reads like a well-organized and coherent text in the readership of the message. In addition, within interactive category, transitions were the most frequent interactive metadiscourse; indicating that the authors were well aware of the usage of these expressions to express the logical relationship between the sentences.

The findings also suggested the idea that as far as the interactive metadiscourse features were concerned, the English authors outperformed the Iranian authors which may support the idea that they were more interested in using the elements by which they could participate the audience in writing process and to help them to understand the goal of the authors. The excessive usage of interactive metadiscourse features by native authors as compared to Iranian non-native authors also indicated that they could manipulate and shape their texts into an organizing and well-established discourse.

In addition, it was concluded that in interactional category of metadiscourse features, the English native writers used more metadiscourse features in comparison to the Iranian non-native authors. In other words, the native authors were more cognizant than the Iranian non-native ones of using interactional metadiscourse features to make the readership engage in the process of writing the message as this is the function of interactional metadiscourse features.

\section{Implications, Limitations and Suggestions for Further Studies}

This study has some implications for second language research. One implication is for instructors in second language domain. The results of the study are practical hints for second language instructors. They can teach metadiscourse feature in academic writing in undergraduate and post graduate courses. Another implication is for researchers who are going to publish research articles. This study can be very useful to them so as to learn how to use metadiscourse features in order to be able to shape a well-organized and coherent text.Also, this study has some implications for those who are interested in the field of contrastive rhetoric. They can benefit from the findings of this research to see how different authors make use of rhetorical devices in their writings to send the message to the receiver. The last, but not the least implication is for researchers in the field of Corpus Linguists. They can learn the way corpora and corpus software can be used in language studies as well as learning the methodology in this field of inquiry.

Like any other research, the current study suffered from a number of limitations some of which could have impacts on the findings of the study. One limitation was that the number of texts in the corpora was not equivalent; although the total number of words was, to a great extent,equivalent. It would be better if the number of texts selected for the study would be equivalence. The other implication was that the author had no access to all papers published in different journals. Indeed, some papers were not downloadable and their authors asked for money for the access. More, the researcher had no control over the age, sex, educational backgrounds and idiosyncrasies of the authors. Also, the researcher had no any knowledge of the authors educational background. Indeed, it was not clear whether or not the authors were experienced in their field of inquiry.

There are also some suggestions for more studies. One suggestion is that the same study can be done by applying other categories of metadiscourse features suggested by other researchers (like Crismore and Kopple). Also, it is recommended that some other comparative studies are done with the aim of comparing the way metadiscourse markers are distributed in other majors and genres. In addition, on study can be conducted in which metadiscourse features are analyzed in terms of distribution and application in papers written by native speakers or non-native speakers of English in other fields of study. Furthermore, a study can be done in which metadiscourse is analyzed in texts written by native speakers and in their translation in a second langue to detect their mode of distribution and applications.

\section{References}

Abdi, Reza, Rizi Tavangar, Manoocher, and Tavakoli, Mansoor. 2010. The cooperative

principle in discourse communities and genres: A framework for the use of metadiscourse. Journal of Pragmatics, 42(6), 1669-1679. doi: 10.1016/j.pragma.2009.11.001. 
Ahangari, Saeideh andMozhgan Kazemi 2014. A Content analysis of 'Alice in wonderland'

regardingmetadiscourse elements. International Journal of Applied Linguistics \& English Literature, 3(3), 10-18. doi: 10.7575/aiac.ijalel. v.3n.3p.10.

Ahmid, Khurshid. 2008. Being in text and text in being: Notes on representative texts.

60-94. InGunilla Anderman and MargaretRogers(eds). Incorporating corpora: the linguist and the translator. Clevedon: Multilingual Matters.

Al samadani, Hashem and Salem Ibnian 2001. Using open-Ended story technique in

improvingSaudiuniversity students' short story writing skills. International Journal of applied linguistics and English Literature, 4(5), 227-233. doi: 10.7575/aiac.ijalel. v.4n.5p.227.

Amiryousefi, Mohammad Javad.,\&Hossein Barati. 2011. Metadiscourse: exploring

interaction in writing, ken Hyland. Elixir Literature, 40, 5245-5250.

Anderman, Gunilla and Margaret Rogers. 2008. Incorporating corpora: the linguist and the translator. Clevedon: Multilingual Matters.

Anwarde,Noor Hafizah, Eunice Ong Luyee, Joanna Indra Gabriel andSeyed Ali Rezvani

Kalajahi, S. A. 2013. An Analysis: The usage of metadiscourse in argumentative writing by Malaysian tertiary level of students. English Language Teaching, 6(9), 83-96. doi:10.5539/elt. v6n9p83.

Awal Norsimah,Imran Ho-Abdullahand IntanSafinazZainudin. 2014. Parallel corpus as a

tool in teaching translation: translating English phrasal verbs into Malay. Procedia - Social and Behavioral Sciences, 112, 882-887. doi: 10.1016/j.sbspro.2014.01.1245.

Baker, Paul, Andrew Hardie and Tony McEnery., 2006. A glossary of corpus linguistics.

Edinburgh: Edinburgh University Press.

Berkenkotter, Carol. Thomas N Huckin. 1995. Genre knowledge in disciplinary

communication: Cognition, culture, power. Hillsdale, NJ: L. Erlbaum Associates.

Bowker, Lynne and Pearson, Jennifer. 2002. Working with specialized language: a practical guide to using corpora. London: Routledge.

Bowker, Lynne and Bennison Peter. 2003. Student translation archive and student translation.

tracking system design, development and application. In Corpora in Translation Education, 103-118. St. Jerome: UK.

Byrnes, H. 2006. The acquisition of German modal particles: A corpus-based

$\begin{array}{lll}\text { approach. Studies in Second } \quad \text { Language } \quad \text { Acquisition, 28(01), } & \text { 130-151. } \\ \text { doi:10.1017/s0272263106330057. }\end{array}$
doi:10.1017/s0272263106330057.

Čermák, F. n.d.. Abstract noun collocations: their nature in a parallel English-Czech

Corpus. 143-153. InBarnbrook, G., Danielsson, P., \&Mahlberg, M. 2006. Meaningful texts: the extraction of semantic information from monolingual and multilingual corpora. London: Continuum International Publishing Group - Academi.

Cheng, Xiaoguang and SteffensenMargaret S. 1996. Metadiscourse: A technique for improving student writing. Research in the Teaching of English, 1(30), 149-181.

Crismore, Avon, Raija Markkane and Margaret S Steffensen.1993. Metadiscourse in persuasivewriting: A study of texts written by American and Finnish university students. Written Communication, 10(1), 39-71. doi:10.1177/0741088393010001002.

Crismore, Avon. 1983. Metadiscourse: What is it and how is it used in school and non-school social science text. University of Illinois at Urbana-Champaign, Technical Reports, 273, 190.

Vaez Dalili, Mehdi and Hossein Vahid Dastjerdi. 2013. A contrastive corpus-based analysis 
of the frequency of discourse markers in NE and NNE media discourse: Implications for a universal discourse competence. Corpus Linguistics and Linguistic Theory, 9(1), 39-69. doi:10.1515/cllt-2013001.

Dias, Gael,Sara Madeira, José Gabriel and Lopes, J. 2005. Extracting concepts from dynamic legislativetext collections. 5-16. InBarnbrook, G. 2006. Meaningful texts: the extraction of semantic information from monolingual and multilingual corpora. London: Continuum.

Eghtesadi, Ahmadreza and Hossein Avidinia.2009. A comparative study of metadiscourse use in research articles written by native and nonnative speakers: Is audience taken into account? The Journal of Asian Tefl, 6(3), 157-176.

Estaji, Masoomeh andRoyaVafaeimehr,2015. A comparative analysis of interactional metadiscourse markers in the introduction and conclusion sections of mechanical and electrical engineering research papers. Iranian Journal of Language Teaching Research, 3(1), 37-56.

Faghih, Esmail and Sepideh Rahimpour, S. 2009. Contrastive rhetoric of English and Persian written texts: Metadiscourse in applied linguistics research articles. Rice Working Papers in Linguistics, 1, 92-107.

Frankenberg-Garcia, Ana. 2009. Are translations longer than source texts? A corpus-based study of explicitation. Corpus Use and Translating Benjamins Translation Library, 47-58. doi: 10.1075/btl.82.05fra.

Gholami, Javad, Sara Rafsanjani Nejad, and Jahanbakhsh Looraji Pour 2014. Metadiscourse markersmisuses; A study of EFLlearners' argumentative essays. Procedia - Social and Behavioral Sciences, 98, 580-589. doi: 10.1016/j.sbspro.2014.03.454.

Gajic, N.2010. Materials development: Corpus-based study of authentic texts for business. San Diego State University, USA: M.A Thesis.

Ghadyani, Fariba andMohamad Hossein Tahririan2015. Interactive markers in medical

researcharticles written by Iranian and native authors of ISI and Non-ISI medical journals: A contrastive Metadiscourse analysis of method section. Theory and Practice in Language Studies, 5(2), 309-317. doi:10.17507/tpls.0502.10

Guo-rong, Shen. 2010. Corpus-based approaches to translation studies. Cross-Cultural Communication, 6(4), 181-187.

Hyland, Ken. 2004. Metadiscourse in academic writing: A reappraisal. Applied Linguistics, 25(2), 156-177. doi:10.1093/applin/25.2.156.

Hyland, Ken. 2005. Metadiscourse: Exploring Interaction in Writing. London: Continuum. Jahin, Jamal Hamed. 2012. The effect of peer reviewing on writing apprehension and essay writingability of prospective EFL teachers. AJTE Australian Journal of Teacher Education, 37(11), 5984. doi:10.14221/ajte.2012v37n11.3.

Kilgarriff, Adam, Vít Baisa, Jan Bušta, Miloš Jakubíček, Vojtěch Kovář, Jan Michelfeit,

Pavel Rychlý and Vít Suchomel. 2014. The Sketch Engine: ten years on. Lexicography, 1(1), 7-36. doi:10.1007/s40607-014-0009-9.

Kopple, Vande. J. 1985. Some exploratory discourse on metadiscourse. College Composition and Communication, 36(1), 82-93. doi:10.2307/357609.

Kuhi, Davud., and Manijeh Mojood.2012. A Contrastive Study of Metadiscourse in English and Persian Editorials. The Journal of Applied Linguistics, 5(1), 137-162.

Mahadi, Sepoa Tengku Mahadi, Hilla Vaezian andMahmoud Akbari. 2010. Corpora in 
translation: a practical guide. Bern: Lang.

Mauranen, Anna. 2004. Spoken corpus for an ordinary learner. in: Sinclair, John McH. (ed.)

How to Use Corpora in Language Teaching. Amsterdam: John Benjamins, 89-105.

McEnery, Tony. and Richard Xiao, 2007 Parallel and comparable corpora: What is happening?

In: Anderman, Gunilla and Rogers, Margaret. (eds). Incorporating Corpora: The Linguist and the Translator. Multilingual Matters, pp. 18-31.

Nesselhauf, Najda. 2004. Learner corpora: Learner corpora and their potential for language teaching. In John McH. Sinclair (eds). How to Use Corpora in Language Teaching. Amsterdam: John Benjamins Pub. Co.

Pooresfahani, Ailin Firoozian, Gholam Hassan Khajavy and Fateme Vahidnia, F. 2012. A

contrastivestudy of metadiscourse elements in research articles written by Iranian applied linguistics and engineering writers in English. English Linguistics Research, 1(1), 88-96. doi:10.5430/elr. v1n1p88.

Prinsloo, Dj andRh Gouws. 2010. The use of examples in polyfunctional

Dictionaries. Lexikos, 10(1), 138-157. doi:10.4314/lex. v10i1.51269.

Salar, Sara andBehzad Ghonsooly 2016. A comparative analysis of metadiscourse features in

knowledge management research articles written in English and Persian. International Journal of Research Studies in Language Learning, 5(1), 1-14. doi:10.5861/ijrsll.2015.1154.

Salem, Ashraf atta.2013. The effect of writer's workshop approach to develop functional

writingskills of primary stage Pre-Service English language teachers in Egypt. International Journal of Applied Linguistics \& English Literature, 2(5), 70-80. doi: 10.7575/aiac.ijalel. v.2n.5p.70.

Serpolet, Noelle. 2008. A study of the mandative subjunctive in French and its translation in

English: A corpus-based contrastive analysis. In Gunilla Anderman and Margaret Rogers, M. 2008. Incorporating corpora: the linguist and the translator. Clevedon: Multilingual Matters.

Sultan, Abbas H.J.2011. A Contrastive study of metadiscourse in English and Arabic

Linguistic Research Articles. Acta Linguistica, 5(1), 28-41.

Tan, Helen. Chan Swee Heng and Ain Nadzimah Abdullah, 2012. A Proposed Metadiscourse

Framework for Lay ESL Writers. World Applied Sciences Journal, 20(1), 1-6. doi:

10.5829/idosi.wasj.2012.20.01.1530.

Tankó, Gyulo. 2004. The use of adverbial connectors in Hungarian university students'

argumentative essays. In (eds), John $\mathrm{McH}$. SinclairHow to Use Corpora in Language Teaching Studies in Corpus Linguistics, 157-181. doi: 10.1075/scl.12.13tan.

Thompson, Geoff and Puleng Thetela. 1995. The sound of one hand clapping: The

managementof interaction in written discourse. Text Interdisciplinary Journal for the Study of Discourse, 15(1) 103-127. doi:10.1515/text.1.1995.15.1.103.

Tsui, Ami B.M. 2004. In preparation: What teachers have always wanted to know - and how corpora can help. In John McH. Sinclair(eds). How to Use Corpora in Language Teaching Studies in Corpus Linguistics, 39-61. doi: 10.1075/scl.12.06tsu.

Utka, A. 2005. Lemmatization and collocational analysis of Lithunian nouns. 107-115. In

Barnbrook, G., Danielsson, P., \&Mahlberg, M. (2006). Meaningful texts: the extraction of semantic information from monolingual and multilingual corpora. London: Continuum International Publishing Group - Academi.

Vande Kopple, Williams. 2012. The importance of studying metadiscourse. Applied 
Research in English, 1(2), 37-44.

Vintar, Špela. 2008. Corpora in Translation: A Slovene Perspective. The Journal of Specialized

Translation, (10), 40-56.

Williams, Joseph M.1981. Style: Ten lessons in clarity and grace. New York: Harper Collins

Publishers.

Yaghoubi, Ahmad and Ardestani Somayeh.2014. Explicit or implicit instruction of

metadiscourse markers and writing skill improvement. International Journal of Applied Linguistics \& English Literature, 3(4), 14-22. doi: 10.7575/aiac.ijalel. v.3n.4p.14

Zadeh, Zahra, RoyaBaharlooei and Simin Shala 2015. Interactive and interactional meta-

discourse markers in conclusion sections of English master theses. International Journal of Research Studies in Language Learning, 4(4), 81-92. doi:10.5861/ijrsll.2015.1081.

Zarei, Gholam andSaraMansoori. 2011. A contrastive study on metadiscourse elements

used inhumanities vs. non humanities across Persian and English. English Language Teaching, 4(1), 42-50. doi:10.5539/elt. v4n1p42.

Zainudin, Intan Safinaz,Nor Hashima Jalaluddin andKhairul Taufiq Abu Bakar2014. The use of

corpus and frame semantics in a lexicography class: evaluating dictionary entries. Procedia - Social and Behavioral Sciences, 116, 2316-2320. doi: 10.1016/j.sbspro.2014.01.566

Zanettin, Federico. 2016. Translation-driven corpora: corpus resources for descriptive and appliedtranslation studies. UK: Routledge.

Gholam, Reza, Gholam reza Zarei, Sara Mansoori.2011. Metadiscursive distinction between

Persian and English: An analysis of computer engineering research articles. Journal of Language Teaching and Research, 2(5), 1037-1042. doi:10.4304/jtr.2.5.1037-1042

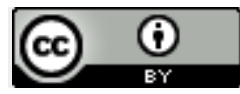

This work is licensed under a Creative Commons Attribution 4.0 International License. 